EESTI RAKENDUSLINGVISTIKA ÜHINGU AASTARAAMAT 1 (2004), 115-137

\title{
VEAD KÕRGTASEMEL EESTI KEELE KÕNELEJATE KIRJALIKUS KEELEKASUTUSES
}

\author{
RAILI POOL, ELLE VAIMANN
}

Ülevaade. Artiklis esitatakse kõrgtasemel eesti keelt teise keelena kõnelejate kirjalikust keelekasutusest kogutud vigade liigitus esinemissageduse alusel. Võrdlusmaterjaliks on sama haridusega eesti keelt emakeelena kõnelejate analoogilistest kirjutistest pärit keelevead. Vaatluse all on nii leksikaalsed kui ka eri valdkondadesse kuuluvad grammatilised vead. Eesmärgiks on välja selgitada vaadeldavate informandirühmade sagedasemad vealiigid ning teise keele kõnelejate puhul tuua välja võimalike interferentsivigade osakaal eri tüüpides.

Võtmesõnad: keeleõpe, keelevead, teise keele kõneleja, emakeelekõneleja, interferents, eesti keel, vene keel

\section{Sissejuhatuseks}

Vigu teevad kõik mingi keele kasutajad, nii teise keelena kui ka emakeelena kõnelejad. Lingvistide jaoks on keelevead huvitav uurimisala, mille puhul tuleb kindlasti arvestada keele kasutusvaldkonda, kust materjal on kogutud. On selge, et näiteks formaalses kirjalikus tekstis esinevaid õigekeelsusvigu ei saa samastada vabas vestluses ette tulevate normingust kõrvalekalletega. Seega tuleks vigu määratledes ja analüüsides kindlasti kirjeldada konteksti, milles need on tehtud. Käesolev artikkel keskendub eesti keelt teise keelena kõnelejate keelevigadele, võrdluseks esitatakse emakeelekõnelejate keelekasutusest kogutud andmed, uurimismaterjal on pärit eksamitöödeks kirjutatud esseedest.

Nii emakeele- kui ka teise keele kõnelejate keelekasutuses tuleb ette nii normatiivse grammatika seisukohast sobimatuid vorme (eesti keeles 
praegu nt *taodeldakse, *kontserdite jms) kui ka suulises kõnes levinud keelevääratusi (slips of the tongue), nagu sõnaalguste äravahetamine jne. Analoogilisi vääratusi kirjalikus keelekasutuses on inglise keeles nimetatud slips of the pen. Kuna keelevääratuse näol on tegemist tahtmatu eksimusega, võib tekkida küsimus, kas seda üldse veaks pidada. Soome keele materjalil põhinevas vastavasisulises uurimuses toob Tapio Hokkanen keelevääratuste vigadeks pidamise kriteeriumidena välja kaks aspekti: need ei väljenda seda, mida algselt taheti öelda ning kõnelejad kalduvad ise oma vigaseid lausungeid parandama (Hokkanen 2001: 31). Keelevääratusi tuleks niisiis pidada üheks emakeele- (ja ka teise keele) kõnelejate vigade liigiks, samas ei sega need enamasti suhtlust, st tegemist ei ole kommunikatiivsete vigadega.

Esimese ja teise keele omandamise vahel on ühe paralleelina toodud välja vigade esinemist mõlemal juhul. Kes on mõlema valdkonnaga kokku puutunud, märkab hõlpsasti, kuivõrd sarnased võivad olla laste vead oma emakeeles ja keeleõppija vead samas sihtkeeles. Keeleõppija vigade analüüsi tunnustatud teoreetik ja hilisem kriitik S. Pit Corder on arvanud, et emakeele ja teise keele omandamine on reguleeritud samade mehhanismide ja strateegiatega ning et teise keele õppimine peaks olema isegi hõlpsam tänu õppija teadmistele oma emakeelest (Corder 1981). Loomulikult ei saa esimese ja teise keele omandamist täielikult samastada ning ka vead vajavad kummalgi juhul erinevat käsitlust. Emakeele omandamisel esinevaid vigu vaadeldakse siirdevormidena, mis emakeelekõneleja kompetentsi saavutamisel kaovad. Teise keele omandajad seevastu saavutavad harva emakeelekõneleja keelepädevuse ning üks silmatorkavamaid põhjusi selleks on kivinenud keelevormide püsimine õppijate vahekeeles. Sihtkeele seisukohast on nende näol tegemist vigadega, mis õpetusele vaatamata ikka ja jälle korduvad ning täielikult ei kao. Constancio K. Nakuma (1998) on võtnud kokku eri uurijate käsitlusi kivinemisest ning toonud välja üldise seisukoha, mille järgi üheks kivinemist mõjutavaks teguriks on ülekanne õppijate esimesest keelest (L1) teise keelde (L2).

Teise keele omandajate vigade uurimise tuntuim meetod on kontrastiivsest analüüsist välja kasvanud veaanalüüs, mis uurib õppijate vigu sihtkeele kontekstis. Veaanalüüsi puhul on välja kujunenud kindlad etapid (Ellis 1994: 48): 1) materjali kogumine; 2) vigade identifitseerimine; 3) vigade klassifitseerimine; 4) vigade seletamine; 5) vigade hindamine. S. Pit Corder (1981) on soovitanud seejuures lahus hoida vead (errors) ja eksimu- 
sed (mistakes), millest esimesed on põhjustatud teadmiste puudumisest, eksimused on aga juhuslikud ning keeleõppijad suudavad neid ise parandada. Kuigi S. Pit Corderi seisukoha järgi peaks veaanalüüs tegelema ainult vigade uurimisega, on tegelikkuses vigade ja eksimuste vahel väga raske vahet teha. Kuigi veaanalüüsi on palju kritiseeritud, eriti veakesksuse tõttu, mis jättis tähelepanuta keeleõppijate korrektse keelekasutuse ning ka võimetuse tõttu arvestada vältimisstrateegiaid ning ennustada vigu (James 1998: 15-18), on keeleõppijate vigade uurimine ka tänapäeval aktuaalne, seda nii efektiivsema keeleõpetamise kui ka teise keele omandamise protsessi uurimise huvides. Veaanalüüs algsel kujul jättis õppijate emakeele täiesti kõrvale, nüüdseks on paljugi ümber hinnatud ja ka eesti keele kui teise keele uurimisel on siinkirjutajate arvates otstarbekas lähtuda Carl Jamesi seisukohast, mille kohaselt teise keele kõnelejate keelekasutuse analüüsimisel tuleks ära kasutada nii kontrastiivse analüüsi, veaanalüüsi kui ülekandeanalüüsi ${ }^{1}$ vahendid ja võimalused, sest keele erinevad valdkonnad nõuavad erinevaid lähenemisviise (James 1994). Kuigi jäigavõitu vahekeele teooria pooldajate arvates tuleks õppijate vahekeelt käsitleda ainult sellest endast lähtudes, otsides ja analüüsides vahekeele sisemisi seaduspärasusi, kusjuures vahekeel tuleks nii lähte- kui sihtkeelest lahus hoida (Lakshmanan, Selinker 2001), on meie arvates õppijakeele uurimisel otstarbekas nii õppijate emakeel kui ka sihtkeel siiski taustal hoida.

Eesti keele kui teise keele alal on veaanalüüsist kirjutatud mitmeid bakalaureusetöid, milles enamasti on käsitletud veaanalüüsi nelja esimest etappi. Viies etapp, vigade hindamine, on eraldiseisev ja teistsugust lähenemisviisi nõudev teema, mille eesmärgiks on välja selgitada, kui raskeks keeleõppijate vigu peetakse. Esimesed sellealased tööd on ka eesti keele kohta juba avaldatud, nt Renate Pajusalu (2004) on käsitlenud tähendusvigade hindamist ja Elle Vaimann eri tüüpi vigade hindamist (uurimuse esialgseid tulemusi vt Vaimann 2002).

Käesolevas artiklis esitame kõrgtasemel eesti keelt teise keelena kõnelejate ning emakeelekõnelejate kirjalikus keelekasutuses esinenud vigade liigid nende esinemissageduse järgi. Veaanalüüsi etappidest on siinses töös niisiis hõlmatud kolm esimest, kusjuures põhirõhk on asetatud kolmandale, vigade klassifitseerimise etapile. Neljas, vigade seletamise etapp, mis tegeleb vigade põhjuste otsimise ja analüüsimisega, on ühes

1 Kontrastiivse analüüsi, veaanalüüsi ja ülekandeanalüüsi olemusest lähemalt vt nt James 1998: 2-6. 
artiklis käsitlemiseks liiga mahukas. Liigitamise kõrval toome välja ainult interferentsist põhjustatud vigade osakaalu eri vealiikides, muid võimalikke vigade põhjusi siinne artikkel ei käsitle.

\section{Artiklis käsitletava uurimuse taustast}

Artikkel põhineb uurimusel, mille materjal on pärit Tartu Ülikooli eesti keele (võõrkeelena) eriala üliõpilaste eesti keele lõpueksami esseedest. Materjal koosneb kahest osast:

1) teise keele kõnelejate (kõigi emakeeleks on vene keel) vead (28 informanti, kokku 664 näidet);

2) emakeelekõnelejate vead (19 informanti, kokku 101 näidet).

Teise keele kõnelejad on emakeelekõnelejatest informantidega oma vanuse ja haridustaseme poolest võrreldavad ning ka materjal on kogutud sarnastes tingimustes kirjutatud esseedest: sama eksam ja sarnane teemadering, võrdne kirjutamisaeg. Teise keele kõnelejatest informantideks on kaasatud kõik üliõpilased, kes materjali kogumise hetkeks olid kõrgtaseme eksami sooritanud. Niisuguse valikupiirangu põhjuseks on soov võimalikult täpselt määratleda informantide keeleoskuse tase, mis on oluline eelkõige muid eesti keelt teise keelena käsitlevaid uurimusi silmas pidades. Sellest, kuidas teise keele omandamise alastes uurimustes informantide keeleoskust on määratletud, annab põhjaliku ülevaate Margaret Thomas (1994). Ta toob välja neli levinuimat viisi: a) uurija subjektiivne hinnang keeleoskusele; b) lähtumine informantide sotsiaalsest staatusest, nt mitmenda aasta ja millise eriala üliõpilastega on tegemist; c) standardtestide tulemuste alusel; d) lähtumine uurija enda koostatud testi tulemustest. Objektiivseimaks neist peab ta taseme määratlemist standardtestide tulemuste põhjal. Siinkirjutajad jagavad seda arvamust, kuna näiteks subjektiivne hinnang, mille kohaselt informandid oskavad keelt üsna hästi, ei pruugi mõne teise uurija arvamusega kokku langeda, inimestel võib olla heast keeleoskusest üsnagi erinev arusaam. Hinnangu andmine uurija enda koostatud testi tulemuste põhjal ei sobi teistele võrdluseks enamasti seetõttu, et väga sageli uurimuste autorid oma testi ei avalda.

Eesti keele oskuse testimiseks on praegu olemas kolme taseme testid alg-, kesk- ja kõrgtaseme määratlemiseks. Samas on kõrgtaseme määratlus väga lai ega diferentseeri õppijaid keeleoskuse järgi piisavalt. Inglise 
keelt kõnelejate liidu² paljudesse keeltesse tõlgitud keeleoskustasemete süsteemi üldskaalal on eesti keele kõrgtasemele vastavaks peetud astmeid 5-8, milles 5. astmel on lubatud sagedased puudused keelekasutuse korrektsuses, samas 8. tasemel kasutab teise keele kõneleja kõiki keelevahendeid peaaegu sama hästi kui oma emakeeles (Hausenberg jt 2003: 1214). Eesti keele kõrgtaseme kirjeldus "Tuul tiibades" (Kerge, Loog 1999) keskendub astmetele 6-7, mööndes, et keelt, sh eesti keelt, on võimalik osata veel kõrgemal, n-ö asjatundja tasemel (proficiency level), millele vastavad tasemed 8-9, kuid sellist suurepärast keeleoskust, mis on lähedane emakeelekõnelejate keeleoskusele, ei ole enam otstarbekas kirjeldada (samas: 15-18).

Subjektiivse hinnangu alusel võime öelda, et meie informantide tegelik eesti keele oskus on küllalt erinev - on neid, kelle keeleoskus võiks vastata tasemete üldskeemi 5. astmele, kuid on ka neid, kes võiksid vähemalt mõne osaoskuse poolest kuuluda 8. tasemele. Kogu meie teise keele kõnelejatest informantide rühm eristub muudest kõrgtasemel eesti keele oskajatest selle poolest, et tegemist on eesti filoloogia üliõpilastega, kes on lisaks laiaulatuslikule praktilise keele õpetusele saanud teoreetilise eesti keele alase hariduse.

Materjal on kogutud seotud tekstist, mitte üksiklausetest, niisiis on kontekstil oluline roll selles, kas mõnda juhtumit veaks pidada või mitte. Näiteks võib üksiklause tunduda vastuvõetavana, kuid laiemas kontekstis võib häirivana mõjuda ajavormi valik. Arvestada tuleb ka asjaolu, et materjali aluseks olevate esseede näol on tegemist vabade kirjutistega, mis küll ühelt poolt annavad pildi informantide produktiivsest keeleoskusest, kuid teisalt jätavad kirjutajatele vabad käed vältimisstrateegiate rakendamiseks. Filoloogiaüliõpilastena on meie teise keele kõnelejatest informantidel kasutada olnud sisendkeel (input; kogu eesti keele aines, millega nad on kokku puutunud, nii teoreetilised teadmised kui keelekeskkonnas omandatu) võimaldanud detailset süvenemist eesti keele struktuuri ja sõnavarasse. Teise keele omandamise alased uurimused on kinnitanud, et keeleõppijad ei mõista mitte kogu neile pakutavat sisendkeelt ja ka sellest, mida nad mõistavad, võetakse tegelikult kasutusse, ehk teisisõnu realiseerub väljundkeelena (output) vaid osa (Siitonen 1999: 26, Ellis 1994: 349). Seejuures annavad keelevead eelkõige tunnistust just sellest, mida õppijad on vastu võtnud, mitte sellest, mida õpetajad arva-

$2 \quad$ English Speaking Union. 
vad olevat õpetanud (Corder 1981). Nimetatud asjaolusid arvesse võttes on siinses artiklis käsitletav materjal vajalik seetõttu, et võimaldab välja selgitada, mida informandid neile pakutud õpetusest on küll reaalselt vastu võtnud ja mis on leidnud väljundi nende produktiivses keeleoskuses, kuid mille puhul ometi eesti keele seisukohast pole tegemist täiesti korrektse keelekasutusega.

Nimetust viga kasutame siinses artiklis mõnevõrra tinglikult. Analüüsitava materjali hulka oleme arvanud kõik juhtumid, mis meile kui emakeelekõnelejatele on mõjunud eesti keele seisukohast häirivana. ${ }^{3}$ Seejuures ei pea alati olema tegemist otseselt normi rikkumisega, näiteks pika ja lühikese pronoomenikuju kasutamine ei olegi eesti keele grammatikas normeeritud, ometi mõjub pika asesõnakuju liigtarvitus lauserõhutus positsioonis emakeelekõnelejale võõrana. Arvestanud oleme ka esseedele esitatavaid nõudmisi, nt oleme vigadena käsitlenud tarbetuid sõnakordusi jms. Mõlema informandirühma kirjutisi oleme käsitlenud samadel alustel. Kuigi vigade määratlemine on alati subjektiivne (eri keeleuurijate ja õpetajate arvamused sellest, mida pidada veaks ja mida mitte, ei pruugi alati kokku langeda, sest inimeste keeletaju on erinev), vähendab käesoleval juhul subjektiivsust loodetavasti asjaolu, et veaks pidamise otsuse taga on kahe inimese arvamus.

\section{Vigade liigitamise erinevaid võimalusi}

Kuna veaanalüüsi üks tähtsamaid eesmärke oli ja on vigade põhjuste väljaselgitamine, on eri autorid aja jooksul välja pakkunud mitmesuguseid vigade liigitusi just nende põhjusi arvesse võttes. Kõigis seesugustes liigitustes on vähemalt üheks oluliseks tüübiks õppijate emakeele mõjul tehtud vigade liik. Näiteks on vigu jagatud kahte suurde rühma: keeltevahelised (põhjuseks esimese keele mõju sihtkeelele) ja keelesisesed vead (põhjuseks sihtkeele reeglite üldistamine, väärvalik vm, mille puhul esimese keele mõju on välistatud) (James 1998: 137-138). Richards (1974,

3 Emakeelekõnelejate keelekasutust on traditsiooniliselt peetud selleks normiks, mille põhjal otsustada teise keele kõnelejate keelekasutuse sobivuse üle. Emakeelekõneleja kõiketeadvat rolli on ka kritiseeritud, vt nt Firth, Wagner 1997. Käesolevas artiklis on autorid võtnud aluseks iseenda kui emakeelekõneleja keeletaju, kuna materjali mahukuse tõttu polnud võimalik suuremat hindajate hulka kasutada. 
viidatud Braidi 1999: 12 järgi) on neile kahele tüübile (emakeele mõjul tehtud vigu on ta nimetanud mitte keeltevahelisteks, vaid interferentsivigadeks, milline nimetus on ka rohkem juurdunud) lisanud veel arenguliste vigade tüübi, need on vead, mis peegeldavad sihtkeele omandamisel rakendatavaid strateegiaid. Tuntud on ka Dulay ja Burti (1973, viidatud Ellis 1994: 28-29 järgi) liigitus vastavalt vigade psühholingvistilisele päritolule, milles on lisaks õppijate emakeele mõjudele arvestatud ka esimese keele omandamise kohta kogutud empiirilisi andmeid. Üks võimalik liigitusalus on veel vea mõjuulatus lauses. Tuntuks on saanud Burti ja Kiparsky (1972, viidatud James 1998: 93, 208 järgi) sellekohane liigitus lokaalseteks ja globaalseteks vigadeks, millest esimesed avaldavad mõju ainult mingile lause üksikelemendile, teised aga kogu lausele.

Vigade käsitlemisel tuleb kindlasti silmas pidada konteksti, milles need esinevad, muidu võib osa vigu ka tähele panemata jääda. Kontekstiga seotuse seisukohast on S. Pit Corder (1973, viidatud James 1998: 93 järgi) eristanud varjatult vigaseid (covertly erroneous) ja ilmselgelt vigaseid (overtly erroneous) näiteid, millest esimesed võivad väljaspool konteksti olla mingitel tingimustel vastuvõetavad, teised aga on sihtkeele seisukohast igal juhul võimatud. Käesolevas töös mängib kontekst vigade määramisel olulist rolli, seega oleme arvesse võtnud nii varjatud kui ilmselged veajuhtumid, mõjuulatust lauses ei ole seejuures oluliseks peetud, niisiis ei hoia me lahus lokaalseid ja globaalseid vigu.

Vigade liigitamisel mitte nende põhjuste, vaid olemuse järgi on põhiküsimuseks see, millised liigid luua ja kui detailne peaks liigitus olema. Eri autorid on vastavalt uuritavale materjalile pakkunud välja erinevaid liigitusvõimalusi. Nii on näiteks K. Bardovi-Harlig ja T. Bofman (1989) jaganud inglise keelt teise keelena õppijate kirjalike tööde vead kolme suurde klassi - süntaktilised, morfoloogilised ja leksikaal-idiomaatilised - ning liigitanud detailsemalt nende klasside sees. Seevastu Charlene G. Polio (1997) on esitanud ainult 38 üksikliigist koosneva kirjalike tööde vigade klassifikatsiooni, liike suurematesse rühmadesse grupeerimata. C. James (1998) kirjeldab mitmesuguseid vigade liigitamise võimalusi. Üheks neist on Dulay, Burti ja Krasheni (1982) poolt esitatud pindstruktuuri taksonoomia, mis põhineb viisidel, mille poolest õppijakeeles esinevad vigased juhtumid erinevad eeldatud sihtkeelepärasest versioonist: 1) väljajätt; 2) lisamine; 3) väärmoodustus; 4) väärjärjestus. C. James (1998: 106-113) omalt poolt lisab sellesse liigitusse veel viienda rühmana 
sulandid (blends). Võimalik lähenemisviis on ka klassifitseerimine lingvistiliste kategooriate alusel. Sel juhul tehakse kõigepealt kindlaks, missugusele keele tasandile viga paigutub: fonoloogia, grafoloogia, grammatika, leksika, tekst, diskursus. Seejärel liigitatakse viga juba vastava tasandi sees klassideks, näiteks kui on tegemist grammatikatasandi veaga, liigitub see edasi nimisõna, tegusõna jne klassi, seal veel omakorda nt arvu, ajavormi jne grammatilisse süsteemi (samas: 104-105).

Käesoleva artikli autorid puutusid töö käigus kokku probleemiga, mida on kirjeldanud ka nt K. Bardovi-Harlig ja T. Bofman (1989) ning Ch. G. Polio (1997). Nimelt esineb materjali hulgas juhtumeid, mille puhul kahe uurija arvamused veaks pidamise või liigitamise osas kokku ei lange. K. Bardovi-Harlig ja T. Bofman (1989) olid vigade suhtes ühel meelel $88 \%$ juhtudest. Käesolevas töös oleme näited, mida üks autor on veaks pidanud ja teine mitte, pidanud otstarbekaks koondada eraldi rühma.

Eesti keelt teise keelena kõnelejate vigade liikidest on seni kirjutatud väga vähe. Venelaste tüüpilisi vigu eesti keeles (ilma arvuliste andmeteta) on käsitletud Irina Külmoja, Eda Vaigla ja Maie Solli eesti-vene kontrastiivse grammatika lühiteatmikus (Külmoja jt 2003: 111-123). Vene emakeelega õppijate kirjutistes esinevate keelevigade omapoolse liigituse on esitanud ka Anna Verschik (2004), millega meie poolt järgnevalt esitatavad tüübid osaliselt sarnanevad. ${ }^{4}$ A. Verschiku ja käesoleva töö ühiseks jooneks on liikide reastamine vastavalt vigade esinemissagedusele.

\section{Vead informantide kirjalikus keelekasutuses nende esinemissageduse järgi 4.1. Kõrgtasemel eesti keelt teise keelena kõnelejate vead}

Veatüüpide järjestamine nende sageduse järgi peaks kõige ülevaatlikumalt illustreerima eesti keele valdkondi, mis kõrgtasemel keeleoskajatele ikka veel probleeme valmistavad. Oleme arvesse võtnud nii leksikaalsed kui ka grammatilised vead ning püüdnud need liigitada võimalikult detailselt. ${ }^{5}$

\footnotetext{
4 Käesoleva artikli ja A. Verschiku (2004) lähtematerjal ei ole täielikult võrreldav, kuna A. Verschik on osa veatüüpe teadlikult kõrvale jätnud.

5 Inglise keelt teise keelena kõnelejate kirjalikest töödest kogutud vigade detailseid liigitusvõimalusi vt Polio 1997.
} 
Eraldi rühma moodustavad nn mehaanilised vead, mille põhjuseks ei ole niivõrd keeleteadmiste puudumine, kuivõrd ilmselt lihtsalt tähelepanematus.

Kuna käesoleva artikli üheks eesmärgiks on vaadelda ka emakeele mõju kõrgtasemel eesti keele kõnelejate keeles, toome näitelausetena ${ }^{6}$ välja nii selliseid, milles esinevaid vigu interferentsiga põhjendada ei saa, kui ka niisuguseid, mille puhul oleks emakeele mõju võimalik, viimasel juhul toome sulgudes ära ka vastava venekeelse struktuuri. Arvulised kokkuvõtted võimalike interferentsivigade kohta on esitatud tabelis 1.

4.1.1. Sõnajärg (117) (sh nii sõnajärjestus NP-s kui ka fraaside järjestus lauses)

- .. see motiveerib unsi kontakte teiste rahvustega looma. (vrd looma uusi kontakte teiste rahvustega)

- Tänapäeval me kõik hästi aru saame, et keeleoskus on saanud hariduse lahutamatuks osaks. (vrd saame me kõik hästi aru, vene мы все хорошо понимаем)

4.1.2. Sõnavalik (92) (alaliigitus asendamist vajava sõna sõnaliigilise kuuluvuse järgi)

Siia on koondatud leksikaalsed vead, mille parandamiseks piisab ühe sõna asendamisest teisega.

1) tegusõna (49)

- Kuigi usun, et ülikool andis mulle palju uusi ja vajalikke teadmisi ning laienes mu silmaringi. (vrd laiendas)

- Ei pea ju teadma selle maa keelt, et lugeda selle maa kirjandust. (vrd oskama, vene знать)

2) nimisõna (26)

- Kvaliteetse hariduse saamine, edukas karjäär, tervislik toitmine,.. (vrd toitumine)

- Kui sissetulekud ei luba inimestel elada nii, nagu nad tahaksid, siis tekib rahuldamatus, tülid ja solvangud. (vrd rahulolematus, vene неудовлетворённость)

\footnotetext{
6 Näitelaused on esitatud autentsel kujul. Alla on joonitud ainult see viga, mis kuulub vaadeldavasse vearühma (samas lauses esinevad muud vead kajastuvad teiste vealiikide andmetes). Üldjuhul on näidetena esitatud terviklaused, vaid väga pikki on osaliselt lühendatud.
} 
EESTI RAKENDUSLINGVISTIKA ÜHINGU AASTARAAMAT 1 (2004)

3) määrsõna (11) (sh määrsõna omadussõna asemel)

- Mõned inimesed juba täiskasvanueas käivad kursustel. (vrd veel)

- Kui mina oleksin kodutu, siis ei oleks mina juba õnnelik. (vrd enam, vene $y ж$ )

- Lihtsamini on elada. (vrd lihtsam, vene легче)

4) omadussõna (8)

- Kas on siis tõeline öelda, et raha avaldab mõju kogu inimese elule .. (vrd oige)

- Mina kui tulevane ema tahan, et minu laste tulevik oleks ónnelik, hele, rõõmus, .. (vrd helge, vene светлое)

5) sidesõna (6)

- On ju huvitav vaadata, kuidas teised inimesed mujal elavad, mis on nende kultuur, kombed ja tavad. (vrd missugused)

- Nii et mitte ainult ajakirjandus mõjutab meie ühiskonda, kui ka meie ühiskond mõjutab ajakirjandust. (vrd vaid ka)

6) asesõna (4)

- Õnneks leidsin ma varsti sõpru minu kursusekaaslaste hulgast .. (vrd oma)

- Minu arvates ülikoolis peab rohkem olema üldaineid nagu ajalugu, kirjandus, psühholoogia, poliitika, võõrkeeled ja teised ained. $\underline{\text { Nad }}$ võimaldavad meil paremini maailma mõista. (vrd need, vene они)

\subsubsection{Täis- ja osasihitise valik (66)}

- Et nendele vastuse leida, tuleb mõtelda selle peale, kust religioon üldse tuleb. (vrd vastust $\mathrm{v}$ vastus)

- .. tema naine jättis teda maha .. (vrd jättis ta maha, vene бросила его (akusatiiv))

\subsubsection{Sõnastus (44)}

Siia on arvatud juhtumid, mille puhul korrektsuse saavutamiseks ei piisa ühe sõna vahetamisest (vrd 4.1.2.), vaid ümber sõnastada tuleb terve lause või osalause.

- Elu näitas oma selga ja seda osa, mis on natuke all. (vrd elu näitas oma pahupoolt)

- Seda kurvem on mõelda selle peale, et kahe kuu pärast lõpeb viimane semester ja kõik osutuvad maailma või vähemalt Eesti erinevates nurkades. (vrd satuvad .. erinevatesse nurkadesse, vene окажутся 6 разных уголках) 
RAILI POOL, ELLE VAIMANN. VEAD KÕRGTASEMEL EESTI KEELE KÕNELEJATE ..

\subsubsection{Pika ja lühikese pronoomenikuju valik (43)}

- Kui mina olen tagasihoidlik inimene ja kardan võoraste inimestega suhtlemist, siis kui tark mina poleks, ei võeta mind tööle. (vrd ma)

- Kuid inimesele on iseloomulik see, et tema ennem märkab ümbritseva maailma ja oma lähedaste puudusi kui enda omi. (vrd ta)

4.1.6. Rektsioon (33) (alaliigitus regeeriva sõna sõnaliigilise kuuluvuse järgi)

1) verbirektsioon (29) (sh $m a$ - ja $d a$-infinitiiv)

- Inimene ópib ka kasutada arvutit .. (vrd kasutama)

- Ma olen väga tänulik ülikoolile selle eest, et ta aitas mulle n.-ö. inimeseks saada. (vrd aitas mul, vene помогал мне)

2) nimisõnarektsioon (3)

- Vastates sellele küsimusele, pean meenutama oma ootusi ülikooli astumise kohta. (vrd ootusi mille suhtes)

- Minu óppimise esimene aasta seostub kõigepealt Tartu tutvumisega. (vrd Tartuga tutvumisega)

\section{3) kaassõnarektsioon (1)}

- Õudne oli näha, mis sellest inimesest sai mõnda aega pärast. (vrd mõne aja pärast, vene через некоторое время)

4.1.7. Vormimoodustus (31) (sh nii verb kui noomen)

- Ausalt öeldes, vene kirjanduse õppetooli loengud olid ainukesed, kus ma ei märkanud üldse aega. (vrd ei märganud)

- Tihti on need rikkaste vanemate lapsed .. (vrd rikaste)

4.1.8. Liigne sõna (23), sh

1) tegusõna (7)

- Mul on olemas üks tuttav naine, kellel on kõrgharidus. (vrd mul on üks ..)

- Koolis pü̈̈аme me saavutada parimat, et saada edasi õppima minna. (vrd et edasi oppima minna, vene .. чтобы можно было идти учиться дальше)

2) määrsõna (7)

- Aga juhtus nii, et ta kaotas töö ära. (vrd kaotas töö)

- Paljud on Lotmani õpilased, mis mõjutab väga tunduvalt nende suhtumist üliõpilastesse. (vrd mõjutab väga v mõjutab tunduvalt)

3) asesõna (5)

- Elus on nii palju huvitavaid asju, mida me saame teha või avastada midagi enda jaoks. (vrd või avastada enda jaoks) 
EESTI RAKENDUSLINGVISTIKA ÜHINGU AASTARAAMAT 1 (2004)

- Minu arust on see lihtsalt ebakorrektne mitte teada eesti keelt. (vrd on lihtsalt .., vene это просто ..)

4) nimisõna (3)

- Suurem osa õpilastest, kes lõpetavad gümnaasiumi, kavatsevad oma õpinguid jätkata üli-ja kõrgkoolides. (vrd kõrgkoolides)

5) kaassõna (1)

- See tähendab seda, et enne ülikooli sisseastumist oli mul hoopis teine elu. (vrd enne ülikooli astumist)

\subsubsection{Ajavorm (22), sh}

1) lihtminevik täismineviku asemel (16)

- Loodan, et teistele tudengitele kinkis ülikool samuti palju häid hetki, mida ei tohi unustada, mis jäi igaveseks südamesse. (vrd on kinkinud, vene подарил)

2) olevik täismineviku asemel (4)

- Mida on mulle andnud ülikool? Kui keegi esitaks mulle sama küsimust mitu aastat tagasi, siis vaevalt ma vastaksin adekvaatselt. (vrd oleks esitanud, oleksin vastanud)

3) täisminevik ennemineviku asemel (1)

- Ülikoolis óppides sain ma külastada mitu Eesti linna, kus mina pole kunagi olnud. (vrd polnud olnud)

4) olevik lihtmineviku asemel (1)

- Olin hämmustunud ka sellest, et mind ümbritseb palju uusi tuttavaid, keda ma leidsin ühiselamusest ja ülikoolist. (vrd ümbritses)

\subsubsection{Käände valik (18)}

Siia on koondatud lausetesse sobimatud käändevormid, mille puhul pole tegemist otseselt rektsioonivigadega (vt 4.1.6.) ega sihitise (vt 4.1.3.) või aluse (vt 4.1.25) käände valikul tehtud vigadega.

- Tol momendil teadsin ainult seda, et ei taha õmblusvabrikul kogu oma elu töötada. (vrd ómblusvabrikus, vene на швейной фабрике)

\subsubsection{Kokku- ja lahkukirjutamine (17)}

- Selline mudel toimib praegu igalpool, igas eluvaldkonnas. (vrd igal pool)

- See võib olla lemmik töö või harrastus: .. (vrd lemmiktöö, vene любимая работа)

4.1.12. Ühildumine (17) (sh nii arvu- kui isikuühildumine)

- Mina ja teised inimesed peavad teda ikka targaks. (vrd peame)

- .. seal maksud on madalam .. (vrd madalamad, vene налоги ниже) 
RAILI POOL, ELLE VAIMANN. VEAD KÕRGTASEMEL EESTI KEELE KÕNELEJATE ..

\subsubsection{Puuduv sõna (15)}

- Siis tema perekonnas on head $\sqrt{ }$ vahelised suhted .. (vrd head inimestevahelised suhted)

- Igal loomal $\sqrt{ }$ oma spetsiifiline, ainult sellele liigile omane, hääletsus .. (vrd igal loomal on, vene y каждого животного)

\subsubsection{Lausete sidumine (7)}

- Kui vaadata maailma peale, kas üldse maailmas keel liidab või lahutab, siis arvan niimoodi. Mõlemad - nii lahutab, kui liidab. (vrd siis arvan, et nii lahutab kui liidab)

\subsubsection{Sõnamoodustus (6)}

- Ja kuna ta on otsusvõimeline inimene, ei ole kahtlust, et kõik saab korda. (vrd otsustusvõimeline)

- On tõesti kurb, et kui keegi on sunnitud mõtlema rahale, unustab ta tihti teisi asju, muutub sallimatuks ümberolijate suhtes .. (vrd ümbritsevate suhtes)

\subsubsection{Arv (5), sealhulgas}

\section{1) ainsus mitmuse asemel (2)}

- Ma räägin vabalt eesti keelt nii tundides, loengutel kui ka kaupluses, apteegis ja muus kohas. (vrd muudes kohtades)

\section{2) mitmus ainsuse asemel (3)}

- Ma kardan igasuguseid pettumusi, meeleheiteid. (vrd meeleheidet)

\subsubsection{Verbivormi valik (5)}

Siia kuuluvad infiniitsed verbivormid, mis on küll korrektselt moodustatud, kuid lause seisukohast sobimatud.

- Samuti jääb lootus, et omandanud eriala aitab neid - selle abil oskaksid need tulevikus parema töö leida. (vrd omandatud)

- Vanemad õpetavad meid lapsepõlves, nad õpetavad, kuidas käituma, mis on hea, mis on halb, mida on lubada teha, mida mitte. (vrd kuidas käituda, on lubatud)

4.1.18. Kõneviis (5) (kindel kõneviis tingiva kõneviisi asemel)

- Vanemad tahavad, et nende lastel oli parem elu, kui on neil. (vrd oleks, vene чтобы у их детей жизнь была лучше)

\subsubsection{Eitav konstruktsioon (5)}

- Võib-olla olen mitte eriti tark, aga täiesti rumalaks ka end ei pea. (vrd ma ei ole eriti tark, venе я не слишком умён)

- . . ja ta ei saa sinust aru või toob mitte seda, mida sa tahtsid. (vrd toob seda, mida sa ei tahtnud, vene принесёт не то, что ты хотел) 
EESTI RAKENDUSLINGVISTIKA ÜHINGU AASTARAAMAT 1 (2004)

\subsubsection{Võrdlusastmed (4)}

- Tartu ülikool oli minu suuremaks unistuseks juba sel ajal, kui ma õppisin keskkoolis. (vrd suurimaks $\mathrm{v}$ kõige suuremaks $\mathrm{v}$ suureks)

- Inimene näeb unistustes oma elu kõige parimana .. (vrd parimana $\mathrm{v}$ kõige paremana, vene самой лучшей)

\subsubsection{Sõnakordus (4)}

- Näiteks võiks tuna vägivaldsuse teemat ajakirjanduses, kuna see on vägagi sagedane ajalehtedes, ajakirjades ning telesaadetes esinev teema.

\subsubsection{Poolitamine (3)}

- Õppisime eksameid poole ööseni, ki-rjutasime spikreid, sooritasime eksameid, käisime diskol ja lihtsalt olime kõik koos. (vrd kir-jutasime)

\subsubsection{Võõrsõnade õigekiri (3)}

- .. lapse seljas on ilus ja kvaliteetne kombenüsoon. (vrd kombinesoon)

\subsubsection{Olematu sõna (2)}

- Tohutavaid elamusi pakuvad tudengite kevadpäevad. (vrd tohutuid)

\subsubsection{Täis- ja osaaluse valik (1)}

- On teosed mida ma hea meelega loeksin vene keeles, mitte eesti keeles. (vrd on teoseid, vene есть произведения)

\section{Mehaanilised vead: ${ }^{7}$}

\subsubsection{Vale täht $(5)$}

- Tänapäeval omandavad kõrgharidust paljud imimesed. (vrd inimesed)

- Anna edasi suur tervutus mehele ja lastele. (vrd tervitus, vene $u=$ eesti $u$ käsikirjalises tekstis)

\subsubsection{Puuduv täht (4)}

- Ette kujutada saaks küll, sellek tuleks vaid oma fantaasiat kasutada. (vrd selleks)

- Võib olla oli vaja varem mõtelda, kelleks mina taha saada. (vrd tahan)

\subsubsection{Tähed vales järjekorras (1)}

- Keda me peame tagraks inimeseks? (vrd targaks)

\subsubsection{Liigne täht (1)}

- Minu näidetest lähtudest ei ole tark inimene mitte alati edukas, vaid edukas inimene on alati tark? (vrd lähtudes)

$7 \quad$ Arvestades informantide ülejäänud teksti, võib selle grupi vigu pidada juhuslikeks. 
Järgmised kolm veatüüpi on paigutatud väljapoole üldist sagedusjärjestust, kuna tegemist on mõneti erandlike rühmadega.

- Kaheti analüüsitavad vead (20)

- Igale on omane unistada ainult parimast tulevikust.

Sellesse tüüpi on arvatud näited, mida oleks võrdselt võimalik liigitada kahte vearühma, toodud näites oleks liigitusvõimalusteks nii sõnavalik (asesõna) (vrd igaühele) kui puuduv sõna (vrd igale inimesele).

- Eri arvamus (16)

- Avastasin nii palju uusi asju, mida varem ei märganud või ei tahtnud märgata.

Siia on koondatud juhtumid, mida üks artikli autoritest on veaks pidanud, teine mitte. Konkreetses näites on üks autoritest konteksti arvestades tajunud ajavormi viga (vrd polnud märganud või polnud tahtnud märgata), teise arvates on lause ka sellisena vastuvõetav.

\section{- Interpunktsioonivead (29)}

- Minu arvates pole vahet $\sqrt{ }$ oled sa buda, luteri või muhamedi usku.

Paljudel juhtudel on kirjavahemärgi panek või panemata jätmine otseselt reegli rikkumine, samas esineb ka näiteid, kus kirjavahemärkide tarvitamist reguleerib kirjutaja soov öeldut rõhutada. Kuna sellistel juhtumitel pole vead üheselt määratletavad, on interpunktsioonivead üldisest sagedusjärjestusest välja jäetud.

\subsection{Emakeelekõnelejate vead}

Eestlaste kirjutistest kogutud vead on liigitatud teise keele kõnelejate vigadega samadel alustel. Kahe informandirühma veatüüpide sagedusjärjestused ei kattu, samuti ei tule kõik teise keele kõnelejate vealiigid emakeelekõnelejate kirjutistes esile.

\subsubsection{Kokku- ja lahkukirjutamine (16)}

- Alles mõned aastad tagasi suheldi omavahel kirjateel. (vrd kirja teel)

- Leian, et tänu eksami eelsele pingeseisundile olen tavaelus palju rahulikumaks muutunud. (vrd eksamieelsele)

4.2.2. Sõnajärg (14) (nii sõnajärjestus NP-s kui ka fraaside järjestus lauses)

- Vahel muudavad su elu täiesti mingid pisikesed valikud, mis sa teinud oled. (vrd mingid täiesti pisikesed valikud) 
EESTI RAKENDUSLINGVISTIKA ÜHINGU AASTARAAMAT 1 (2004)

- On selge, et suurt süsteemi tervikuna ümberstruktureerida ei saa paari aastaga, kuid .. (vrd süsteemi tervikuna paari aastaga ümber struktureerida ei saa)

\subsubsection{Sõnastus $(10)$}

- Inimene pole täiuslik: tal on vead, aga need vead on halvad. (vrd .. : igaühel on omad vead)

- Keskmistel lehekülgedel olid koos fotodega välja toodud viiekümne Rootsi suurema sissetulekuga naised. (vrd olid välja toodud Rootsi viiekümne suurima sissetulekuga naise fotod)

4.2.4. Sõnavalik (7) (alaliigitus asendamist vajava sõna sõnaliigilise kuuluvuse järgi)

1) nimisõna (5)

- Rahu, tahame elada rahus, olla õnnelikud - niisuguste naiivsetekillast hü̈̈unditega puutume sageli kokku. (vrd hü̈̈dlausetega)

\section{2) kaassõna (2)}

- Rumalamad nõuavad ja raevutsevad, kalduvad äärmustesse ja ei anna järgi. (vrd ei anna järele)

\subsubsection{Poolik lause (4)}

- Tema suudab hetkel pakkuda mulle kõike seda, mis on vajalik, et olla onnelik. Mitte materiaalselt.

\subsubsection{Puuduv sõna (4)}

- See pole ju mitte midagi mund kui $\sqrt{ }$ peale surumine. (vrd enese pealesurumine)

\subsubsection{Lausete sidumine (3)}

- Haridussüsteem iseenesest aga on tundlik valdkond, sest see puudutab otseselt noort, arenevat ja kasvavat inimest, keda on suhteliselt kerge mõjutada ning kes ehk pole veel enesele jõudnud paksu nahka kasvatada. Samuti ümbritseva suhtes teatavat immunnsust tekitada. (vrd .. paksu nahka kasvatada ega ümbritseva ..)

\subsection{8. Ühildumine (3)}

- Arvan, et raha on oluline, kuna raha abil on võimalik rahuldada teatuid vajadusi ja soove. (vrd teatud vajadusi ja soove)

\subsubsection{Vormimoodustus (2)}

- Selline jutt võib tunduda ideaalitseva ja kulununa ning selle võib mitmet moodi ümber lükata ja tühiseks kuulutada. (vrd mitut moodi) 
RAILI POOL, ELLE VAIMANN. VEAD KÕRGTASEMEL EESTI KEELE KÕNELEJATE ..

\subsubsection{Sõnakordus (2)}

- Raskem on aga neil noortel, kes on oma iseseisvat elu alustamas. Kergem on muidugi sellistel noortel, kes on suutnud leida endale hea töökoha. Raskem on aga sellistel noortel, kel pole tööd, haridust ega vanematepoolset toetust.

4.2.11. Ajavorm (1) (lihtminevik täismineviku asemel)

- Sidevahendite kvatiteedi paranemisega muutus ka inimestevaheline suhtlemine. (vrd on muиtunud)

4.2.12. Täis- ja osasihitise valik (1)

- Kuid teisest küljest vaadates, julgevad ka muidu häbelikud ja tagasihoidlikud inimesed avaldada oma arvamust, võtta osa aruteludest, või leida isegi südamesõber ja seda tänu internetile. (vrd südamesõbra)

\subsubsection{Käände valik (1)}

- Alati on igal asjal oma head ja halvad küljed. Nii ka arvutiga. (vrd nii ka arvutil)

\subsubsection{Liigne sõna (1)}

- Ühel suvekuupäeval Stockholmi vanalinnas jalutades pisteti mulle pihku mingi brošüür, mis hilisemal vaatlemisel osutus ajakirjaks ajakirjaks, mis avas mu silmad. (vrd ühel suvepäeval)

\section{Mehaanilised vead:}

\subsubsection{Vale täht $(5)$}

- Eelpool välja toodud näidete taustal võib tegelikult mistahes rahvad jagade kahte rühma. (vrd jagada)

\subsubsection{Liigne täht (2)}

- Tahtes üha rohkem ja rohkem nii materiaalseid hüvesid (näit. vallutamise au), võttis ta need endale omatahitsi, vastu kellegi teise tahtmist. (vrd omatahtsi)

Samadel alustel nagu teise keele kõnelejate vigade puhul, on ka siin järgmised kolm veatüüpi esitatud väljaspool üldist sagedusjärjestust.

\section{- Kaheti analüüsitavad vead (2)}

- Kuid pole kindel, kas meie, noorem põlvkond, päris täpselt oskabki ette kujutada, mis on sõda. (ühildumine, vrd oskamegi või interpunktsioon, vrd kas meie noorem põlvkond päris täpselt oskabki ..) 
- Eri arvamus (5)

- Ühesõnaga, eestlaste seaski on rootslasi ja vastupidi. (sobib nii või sõnavalik)

- Interpunktsioon (21)

- Maja, milles nad elavad $\sqrt{ }$ on hiiglaslik. (koma puudu)

\subsection{Kokkuvõtteks}

Tabel 1 võtab kokku eesti keele valdkonnad, milles teise keele kõnelejatest informantidel vaatamata praktilisele ja teoreetilisele eesti keele alasele ettevalmistusele ning vältimisstrateegiate kasutamise võimalusele ikka veel lünki esineb. Seejuures tuleb arvestada, et liigituse aluseks on kirjalik keelekasutus, see määrab paljuski nii vigade liigid kui ka selle, mida üldse veaks pidada. Ainult kirjaliku materjali põhjal kujunevad sellised liigid nagu poolitamine ja kokku- ja lahkukirjutamine ning ka lausete sidumist ja sõnakordust ei saaks suulisest kõnest kogutud materjali põhjal samadel alustel vigadeks pidada nagu esseede puhul. Nn mehaaniliste vigade rühma võiks käsitada ka kirjalikus keeles esinevate vääratustena (nn slips of the pen).

Antud tingimustes kujunes sagedasimaks vealiigiks sõnajärg, mis oli ka emakeelekõnelejatest informantide rühmal esimeste hulgas. Teise keele kõnelejate kirjutistes esines palju ka leksikaalseid vigu (sõnavalik ja sõnastus). Täis- ja osasihitise kasutamist on traditsiooniliselt peetud eesti keele kui teise keele õppijate komistuskiviks, seda emakeelest olenemata ning siinne materjal kinnitab selle üldlevinud arvamuse paikapidavust ka kõrgtasemel informantide puhul. Objektikäänete ja leksikaalsete vigade osas on tulemused käesoleva töö ja A. Verschiku (2004) materjali vahel üsna sarnased, meie liigituses on sõnavalikuvead sageduselt teisel ja objektivead kolmandal kohal, A. Verschiku töös on esikohal semantilised ning teisel kohal sihitisevead.

Mõneti üllatav on pika ja lühikese pronoomenikuju valiku vigade paigutumine sageduselt 5. kohale. Siin mängivad aga olulist rolli õppijate individuaalsed iseärasused. Nimelt jaguneb selle liigi suhteliselt suur näidete arv (43) väga väheste informantide vahel, näiteks ühel inimesel on 17, ühel 11, ühel 5, ühel 2 ja kaheksal 1 viga, samas kui 16 informanti ei ole seda tüüpi viga üldse teinud. Võrdluseks: objektivigu esines 25 
RAILI POOL, ELLE VAIMANN. VEAD KÕRGTASEMEL EESTI KEELE KÕNELEJATE .

Tabel 1. Arvulised andmed vigade esinemissageduse kohta

\begin{tabular}{|c|c|c|c|c|c|c|}
\hline \multirow{3}{*}{ VIGADE LIIGID } & \multirow{2}{*}{\multicolumn{2}{|c|}{$\begin{array}{c}\text { Teise keele } \\
\text { kõnelejate } \\
\text { vead }\end{array}$}} & \multicolumn{2}{|c|}{$\begin{array}{c}\text { Interferentsivigade } \\
\text { osakaal }\end{array}$} & \multirow{2}{*}{\multicolumn{2}{|c|}{$\begin{array}{l}\text { Emakeele- } \\
\text { kõnelejate vead }\end{array}$}} \\
\hline & & & \multirow{2}{*}{$\begin{array}{c}\begin{array}{c}\text { Interfe- } \\
\text { rents }\end{array} \\
n\end{array}$} & \multirow{2}{*}{$\begin{array}{c}\text { Muud } \\
\text { põhjused } \\
n\end{array}$} & & \\
\hline & $\mathrm{n}$ & $\%$ & & & $\mathrm{n}$ & $\%$ \\
\hline 1. Sõnajärg & 117 & 17,6 & 56 & 61 & 14 & 13,9 \\
\hline 2. Sõnavalik & 92 & 13,9 & 40 & 52 & 7 & 6,9 \\
\hline 3. Täis- ja osasihitis & 66 & 9,9 & 48 & 18 & 1 & 1,0 \\
\hline 4. Sõnastus & 44 & 6,6 & 19 & 25 & 10 & 9,9 \\
\hline 5. $\quad$ Pronoomenikuju & 43 & 6,5 & - & 43 & - & - \\
\hline 6. Rektsioon & 33 & 5,0 & 12 & 21 & - & - \\
\hline 7. Vormimoodustus & 31 & 4,7 & - & 31 & 2 & 2,0 \\
\hline 8. $\quad$ Liigne sõna & 23 & 3,5 & 3 & 20 & 1 & 1,0 \\
\hline 9. Ajavorm & 22 & 3,3 & 16 & 6 & 1 & 1,0 \\
\hline 10. Käände valik & 18 & 2,7 & 7 & 11 & 1 & 1,0 \\
\hline $\begin{array}{l}\text { 11. Kokku- ja } \\
\text { lahkukirjutamine }\end{array}$ & 17 & 2,6 & 9 & 8 & 16 & 15,9 \\
\hline 12. Ühildumine & 17 & 2,6 & 7 & 10 & 3 & 3,0 \\
\hline 13. Puuduv sõna & 15 & 2,3 & 5 & 10 & 4 & 4,0 \\
\hline 14. Lausete sidumine & 7 & 1,1 & - & 7 & - & - \\
\hline 15. Sõnamoodustus & 6 & 0,9 & - & 6 & - & - \\
\hline 16. Arv & 5 & 0,8 & 3 & 2 & - & - \\
\hline 17. Verbivormi valik & 5 & 0,8 & - & 5 & - & - \\
\hline 18. Kõneviis & 5 & 0,8 & 5 & - & - & - \\
\hline 19. Eitav konstruktsioon & 5 & 0,8 & 5 & - & - & - \\
\hline 20. Võrdlusastmed & 4 & 0,6 & 1 & 3 & - & - \\
\hline 21. Sõnakordus & 4 & 0,6 & - & 4 & 2 & 2,0 \\
\hline 22. Poolitamine & 3 & 0,5 & 2 & 1 & - & - \\
\hline 23. Võõrsõnade õigekiri & 3 & 0,5 & - & 3 & - & - \\
\hline 24. Olematu sõna & 2 & 0,3 & - & 2 & - & - \\
\hline 25. Täis- ja osaalus & 1 & 0,2 & 1 & - & - & - \\
\hline 26. Poolik lause & - & - & - & - & 4 & 4,0 \\
\hline \multicolumn{7}{|l|}{ Mehaanilised vead } \\
\hline 27. Vale täht & 5 & 0,8 & 1 & 4 & 5 & 5,0 \\
\hline 28. Puuduv täht & 4 & 0,6 & - & 4 & - & - \\
\hline $\begin{array}{l}\text { 29. Tähed vales } \\
\text { järjekorras }\end{array}$ & 1 & 0,2 & - & 1 & - & - \\
\hline 30. Liigne täht & 1 & 0,2 & - & 1 & 2 & 2,0 \\
\hline \multicolumn{7}{|l|}{ Mund juhtumid } \\
\hline $\begin{array}{l}\text { 31. Kaheti } \\
\text { analüüsitavad vead }\end{array}$ & 20 & 3,0 & 8 & 12 & 2 & 2,0 \\
\hline 32. Eri arvamus & 16 & 2,4 & 11 & 5 & 5 & 5,0 \\
\hline 33. Interpunktsioon & 29 & 4,4 & 2 & 27 & 21 & 20,8 \\
\hline Kokku & 664 & 100,0 & $\begin{array}{c}261 \\
(39,3 \%)\end{array}$ & $\begin{array}{c}403 \\
(60,7 \%)\end{array}$ & 101 & 100,0 \\
\hline
\end{tabular}


informandil 28-st ning sõnajärjevigu ei olnud ainult ühe informandi töös. Õppijate individuaalseid iseärasusi, sealhulgas näiteks seda, milliseid vorme konkreetsete informantide vahekeeles võiks käsitleda kivinemistena, ei ole siinses artiklis võimalik põhjalikumalt käsitleda.

Tabelis on välja toodud ka andmed selle kohta, kui suur hulk vigu võib olla tingitud negatiivsest ülekandest õppijate emakeelest ehk interferentsist. ${ }^{8}$ Seejuures tuleb kindlasti arvestada, et vigade puhul ei saa rääkida ainult ühest kindlast põhjusest, enamasti on mingi vea taustaks mitme teguri omavaheline koosmõju. Nii tuleks meie poolt esitatud andmeid käsitada viisil, et interferents oli neil juhtudel võimalik, kuid mitte tingimata ainus vigu põhjustanud faktor. Eesti ja vene keele vahelised struktuurierinevused välistavad osas tüüpides interferentsi täielikult (nt pika ja lühikese pronoomenikuju valiku vead, vormimoodustusvead jm). Emakeele mõju tuleb kõige enam esile objektivigades (eesti keele partitiivobjekti võib olla mõjutanud vene keele akusatiiv), sõnajärjes, sõnavalikus, sõnastuses ja rektsioonis. Kogu vaadeldud näitematerjalist on 39,3\% vigadest võimalik pidada interferentsivigadeks, ülejäänud $60,7 \%$ juhtudest on tegemist muude põhjustega. Interferentsivigade hulka oleme arvestanud ka nn varjatud interferentsi juhtumid, mille puhul kahe keele struktuur pole täielikult sarnane, kuid on põhjust arvata, et õppijad on eesti keeles tehtud valikutel lähtunud emakeelest. Suurim rühm on siin ajavormivead, mille puhul vene keele ainus minevikuvorm on käesoleva uurimuse informantide vahekeeles üldistunud lihtminevikuna, jättes kõrvale täis- ja ennemineviku. Huvitav on märkida, et materjalis puudusid täielikult ajavormivead, mille korral lihtmineviku asemel oleks tarvitatud täisminevikku, mis on keeleõppijate puhul väga tüüpiline, ning et ülekanne emakeelest on võimalik ka nn mehaaniliste vigade rühmas (vt 4.1.26.).

\section{Lõpetuseks}

Sarnase filoloogilise haridusega teise keele kõnelejatest ja emakeelekõnelejatest informantide kirjalikus keelekasutuses ilmnes tendents, et teise keele kõnelejate suurima esinemissagedusega vealiigid osutusid veaohtlikeks ka emakeelekõnelejatel. Nii esines mõlemal informandirühmal roh-

8 Otsustamaks, millistel juhtudel võib olla tegemist interferentsivigadega, on kasutatud eesti keelt kõrgtasemel valdavate vene keelt emakeelena kõnelejate abi. 
kesti sõnajärje-, sõnastus- ja sõnavalikuvigu. Mõneti üllatavalt mõjus emakeelekõnelejate interpunktsiooni- ning kokku- ja lahkukirjutamise vigade märgatavalt suurem osakaal, võrreldes teise keele kõnelejate samalaadsete vigadega.

Siinses artiklis käsitlesime filoloogilise haridusega eesti keelt teise keelena kõnelejate vealiike. Millised vealiigid on iseloomulikud mittefiloloogidest kõrgtasemel eesti keele kõnelejatele, kas ja kuivõrd erinevad alg-, kesk- ja kõrgtasemel eesti keele kõnelejate vead, millised on täpsemalt nende vigade põhjused (nt kas võimalike interferentsivigade osakaal eri tasemetel on erinev) ning kas eri emakeeltega õppijate veatüübid kattuvad - see vajaks edasist uurimist.

\section{Kirjandus}

Bardovi-Harlig, Kathleen \& Bofman, Theodora 1989. Attainment of syntactic and morphological accuracy by advanced language learners. - Studies in Second Language Acquisition 11, 17-34.

Braidi, Susan 1999. The Acquisition of Second-Language Syntax. London: Arnold.

Corder, S. Pit 1981. The significance of learner's errors'. - Error Analysis and Interlanguage. Oxford: Oxford University Press, 5-13. [Reprinted from International Review of Applied Linguistics 1967, Vol. 5, No. 4, 161-170.]

Ellis, Rod 1994. The Study of Second Language Acquisition. Oxford: Oxford University Press.

Firth, Alan \& Wagner, Johannes 1997. On discourse, communication, and (some) fundamental concepts in SLA research. - The Modern Language Journal 81, 285-300.

Hausenberg, Anu-Reet \& Kikerpill, Tiina \& Rõigas, Maia \& Türk, Ülle 2003. Keeleoskuse mõõtmine. Tallinn: TEA Kirjastus.

Hokkanen, Tapio 2001. Slips of the Tongue. Errors, Repairs and a Model. Finnish Literature Society. Helsinki.

James, Carl 1994. Don't shoot my dodo: on the resilience of contrastive and error analysis. - IRAL: International Review of Applied Linguistics in Language Teaching Vol. 32. Issue 3, 179-201.

James, Carl 1998. Errors in Language Learning and Use. Exploring Error Analysis. London and New York: Longman.

Kerge, Krista \& Loog, Mai 1999. Tuul tiibades. Eesti keele suhtluse kõrgtase. Riiklik Eksami- ja Kvalifikatsioonikeskus. Tallinn.

Külmoja jt = Кюльмоя, Ирина \& Вайгла, Эда \& Солль, Майе 2003. Краткий справочник по контрастивной грамматике эстонского и русского языков. Тарту: Tartu Ülikooli Kirjastus. 
Lakshmanan, Usha \& Selinker, Larry 2001. Analysing interlanguage: how do we know what learners know? - Second Language Research 17, 4, 393-420.

Nakuma, Constancio K. 1998. A new theoretical account of 'fossilization': implications for L2 attrition research. - IRAL: International Rewiew of Applied Linguistics in Language Teaching Vol. 36, Issue 3, 247-257.

Pajusalu, Renate 2004. Keeleõppija tähendusviga ja selle hindamine. - Toimiv keel II. Töid rakenduslingvistika alalt. Koost Helle Metslang, toim Maria-Maren Sepper, Jane Lepasaar. TPÜ eesti filoloogia osakonna toimetised 3. Tallinn: TPÜ Kirjastus, 218-235.

Polio, Charlene G. 1997. Measures of linguistic accuracy in second language writing resarch. - Language Learning 47, 1, 101-143.

Siitonen, Kirsti 1999. Agenttia etsimässä. $u$-verbijohdokset edistyneen suomenoppijan ongelmana. Väitöskirja. Turun yliopiston suomalaisen ja yleisen kielitieteen laitoksen julkaisuja 63. Turku.

Thomas, Margaret 1994. Assessment of L2 proficiency in second language acquisition research. - Language Learning 44, 2, 307-336.

Vaimann, Elle 2002. Mis on eesti keeles viga? - Emakeel ja teised keeled III. Toim Liina Lindström, Oksana Palikova. Tartu Ülikooli eesti keele (võõrkeelena) õppetooli toimetised 1. Tartu: Tartu Ülikooli Kirjastus, 250-257.

Verschik, Anna 2002. Viga! Viga? Viga ... - Oma Keel 2, 76-82.

Verschik, Anna 2004. Mõnda vahekeelest ja kontrastiivsest analüüsist. - Eesti keel: võõrkeelest teiseks keeleks. Koost Mart Rannut, toim Mart Rannut, Marju Kõivupuu, Tiit Päeva. TPÜ eesti filoloogia osakonna toimetised 1. Tallinn: TPÜ Kirjastus, 132-144.

\section{Kaudviited}

Burt, Marina K. \& Kiparsky, Carol 1972. The Gooficon: A Repair Manual for English. Rowley, MA: Newbury House.

Corder, S. Pit 1973. Introducing Applied Linguistics. Harmondsworth: Penguin.

Dulay, Heidi \& Burt, M. 1973. "Should we teach children syntax?" - Language Learning 23, 245-258.

Dulay, Heidi \& Burt, Marina \& Krashen, Stephen 1982. Language Two. Rowley, MA: Newbury House.

Richards, Jack C. 1974. A non-contrastive approach to error analysis. - Error Analysis: Perspectives on Second Language Acquisition. Ed. by Jack C. Richards. London: Longman, 172-88. [Reprinted from English Language Teaching 25.] 


\section{Errors in written Estonian by advanced level speakers}

RAILI POOL, ELLE VAIMANN

This article presents categories of errors made by non-native Estonian speakers in order of frequency of occurrence. This compilation of errors was compared with the errors made by native Estonian speakers. Both groups consisted of students of the Estonian as Foreign Language Department, University of Tartu. The compilation of errors (664 errors by non-native speakers, 101 by native speakers) was gleaned from the composition portion of the Estonian language final examination. The errors made by non-native speakers were also examined for possible influences by the native language (L1).

The most common error category by non-native speakers was word order (17.6\%), followed by word choice (13.9\%), incorrect object case $(9.9 \%)$ and improper phrasing (6.6\%). Errors caused by interference were found most frequently in the object, followed by word order, lexical errors and government. Possible interference errors comprised 39.3\% of the total error count.

Written errors by native Estonians were dominated by improper construction of compound words (15.9\%), followed by word order $(13.9 \%)$ and lexical errors: phrasing $(9.9 \%)$ and word choice $(6.9 \%)$.

A comparison of the native and non-native speaker groups (who both share the same philological education) revealed that both tend to err in the same category.

RAILI POOL (1969) on lõpetanud Tartu Ülikooli eesti filoloogia erialal 1992. a, samast aastast töötab Tartu Ülikooli eesti keele (võõrkeelena) õppetoolis. Kaitses magistrikraadi Tartu Ülikoolis 1999. a eesti keele alal. Peamiseks uurimisvaldkonnaks on eesti keele kui teise keele omandamine ja kasutus.

raili.pool@ut.ee

ELLE VAIMANN (1960) on lõpetanud 1983. a Tartu Ülikooli eesti filoloogia erialal. Aastast 1993 töötab Tartu Ülikooli eesti keele (võõrkeelena) õppetoolis. Uurimisvaldkonnaks on keelevigadega seonduvad küsimused.

elle.vaimann@ut.ee 